\title{
Effect of shade cloth on fruit and leaf nutritional concentration and bitter pit incidence in 'Fuji' apples
}

\author{
Juan Hirzel $^{{ }^{*} \text {, Ernesto Moya-Elizondo }}{ }^{2}$, Macarena Hernández ${ }^{3}$, Pedro Guzmán ${ }^{3}$, \\ and Dagoberto González ${ }^{3}$
}

\begin{abstract}
'Instituto de Investigaciones Agropecuarias, INIA Quilamapu, Av. Vicente Méndez 515, Chillán, Chile.
"Corresponding author (jhirzel@inia.cl).

${ }^{2}$ Universidad de Concepción, Facultad de Agronomía, Av. Vicente Méndez 595, Chillán, Chile.

${ }^{3}$ Exportadora UNIFRUTTI Traders Ltda., Longitudinal Sur km 300, Linares, Chile.
\end{abstract}

Received: 13 April 2020; Accepted: 29 June 2020; doi:10.4067/S0718-58392020000400535

\begin{abstract}
Shade cloth is commonly used to reduce incident light in apple (Malus domestica [Suckow] Borkh.) orchards. Nevertheless, this technology can generate changes in plant physiology that affect tissue nutritional composition and cause fruit nutritional disorders. The effect of shade cloth on the nutritional concentration of six macroelements and six microelements on leaves, six macronutrients in the fruits of 'Fuji' apples, and bitter pit incidence was assessed in a study conducted in a commercial orchard in south-central Chile for three seasons. Two treatments (control without shade cloth and $30 \%$ shade cloth cover) were evaluated with five replicates in a split plot design. Averaged results for the three seasons showed that shade cloth increased $\mathrm{Mg}, \mathrm{Mn}$, and $\mathrm{Zn}$ concentrations in leaves by $0.02 \%, 40 \mathrm{mg} \mathrm{kg}^{-1}$, and $5.5 \mathrm{mg} \mathrm{kg}^{-1}$, respectively, and decreased $\mathrm{K}, \mathrm{Mg}$, and $\mathrm{S}$ concentrations in fruits by $12,0.35$, and $0.38 \mathrm{mg} 100 \mathrm{~g}^{-1}$ fresh fruit, respectively. Bitter pit incidence was not affected by shade cloth (values between $0.3 \%$ and $6.6 \%$ ), but seasonal conditions did affect this abiotic disorder. In conclusion, the use of shade cloth in apples did not affect bitter pit incidence, but it caused some changes in leaf and fruit nutritional concentration.
\end{abstract}

Key words: Bitter pit, Malus domestica, nutrients, shade cloth.

\section{INTRODUCTION}

Fruit production currently includes modern management practices and high-technology production systems, which are associated with the use of cover crops for weed control, integrated pest and disease management, high density planting, pedestrian orchards, mechanical high-pressure irrigation systems, and the use of netting or covers to protect against excessive radiation. The combination of modern management practices and high-technology systems allows profitable production and fruit quality according to customer requirements. The use of netting or cover has increased considerably in the last decade, especially in orchards with species such as apple (Blanke, 2007), wine grapes (Martínez-Lüscher et al., 2017), peach (Baraldi et al., 1998), kiwifruit (Basile et al., 2008), blueberry (Kim et al., 2011; Lobos et al., 2013), and lemon (Li and Syvertsen, 2006). This high-technology system has also been used in vegetable crops such as tomato (Sandri et al., 2003).

The use of shade cloth in agricultural production and in specific orchards has a protective function against excessive radiation on the fruits, and this technology could mitigate adverse effects of climate change on fruit trees (Demchak, 2009). Bassett et al. (2006) pointed out that photoselective netting substantially reduces environmental temperature and 
generates morphological and physiological variations in the plant, which could lead to delayed fruit ripening, given that the development of external fruit color is associated with the quality and amount of incident light. Ban et al. (2007) indicated that light can regulate gene transcription associated with peel color in apple, particularly UV-B radiation. Du et al. (2014) mentioned that abiotic stresses, such as UV exposure, affect the pathways involved in the biosynthesis of the principal groups of secondary metabolites (phenolics, terpenes, and $\mathrm{N}$-containing compounds) in fruit and vegetables included in the human diet; these could reduce the accumulation of important antioxidant compounds beneficial for human health. Du et al. (2014) indicated a negative effect of different UV-B doses $\left(1.3,3.1\right.$, and $\left.5.9 \mathrm{~kJ} \mathrm{~m}^{-2}\right)$ on the total soluble phenolics in fruit wedges of 'Golden Delicious' and 'Red Delicious' apples after $72 \mathrm{~h}$ storage at $15^{\circ} \mathrm{C}$; there was a major effect on 'Golden Delicious' associated with increased UV-B light intensity. In addition, Kim et al. (2011) showed that light quality affects leaf morphology and the gas exchange function and capacity. Those changes could also affect the nutritional composition in leaves and other structures such as fruits. Reported benefits of shade cloths include improved blueberry fruit quality (Lobos et al., 2013), changes in the development of apple color (Blanke, 2007), increased photosynthesis in blueberry (Kim et al., 2011), increased yield with reduced blueberry fruit firmness (Retamal-Salgado et al., 2017), decreased pH and increased titratable acidity in grapes (Martínez-Lüscher et al., 2017), reduced bacterial disease in kiwifruit plants (Chiabrando and Giacalone, 2018), and decreased direct sun damage in apples related to increased photosynthetic efficiency on fruit peel by reducing excess light energy and fruit temperature (Olivares-Soto and Bastías, 2018).

Shade cloths used in orchards and on horticultural crops can affect both fruit and leaf nutrient concentrations because greater or lesser light incidence can alter transpiration rates, which can generate an increased or decreased concentration of some nutrients and organic compounds in cultivated plants. Changes in starch content associated with variations in the inorganic $\mathrm{P}(\mathrm{Pi})$ concentration in tomato leaf $v s$. greater or lesser light incidence have been reported by Ayari et al. (2000). Mohotti and Lawlor (2002) found that shade application affected $\mathrm{N}$ concentration in tea leaves, so that plants treated with heavy and medium shade cloth had higher leaf $\mathrm{N}$ content (mean 2.6\%) compared with unshaded plants (2.29\%).

Beech (Fagus sylvatica L.) seedlings evaluated under three light environments (high, intermediate, and low light conditions) showed that leaf chlorophyll concentrations decreased, and nutrient use efficiency increased when light increased (Minotta and Pinzauti, 1996).

Leaf and fruit nutrient concentrations can be affected by different factors. For example, variations over time associated with the age of leaves and fruits and nutrient mobility to fruits during growth have been demonstrated in kiwifruit (Smith et al., 1988), olive (Sharma et al., 2005), sweet cherry (Fernández et al., 2014), and blueberry (Castillo-González et al., 2016). There is no scientific information that associates changes in the nutrient concentration in tissues of different ages with the incident light level. In addition, changes in fruit nutrient concentration could increase or decrease the incidence of nutritional disorder in species that exhibit some disorder such as bitter pit in apple (Lötze et al., 2006; Lötze and Theron, 2007), cork spot in pear (Duan et al., 2019), and blossom-end rot in tomato (Ho et al., 1999; Sun et al., 2013). De Freitas et al. (2013) indicated that shade on 'Greensleeves' apple trees increases both fruit $\mathrm{Ca}^{2+}$ and $\mathrm{Mg}^{2+}$ uptake and fruit susceptibility to bitter pit by increasing $\mathrm{Mg}^{2+}$ uptake and $\mathrm{Ca}^{2+}$ binding to the cell wall in fruit cortical tissue.

Physiological problems of fruits at postharvest are usually associated with nutrients related to Ca deficiency; several authors have found that it is not sufficient to determine the Ca concentration (Le Grange et al., 1998; Lötze et al., 2006). Le Grange et al. (1998) mentioned that the individual Ca concentration in apple fruits is not a good predictor of risk for bitter pit.

In addition, Lötze et al. (2006) indicated the importance of determining the $\mathrm{N} / \mathrm{Ca}, \mathrm{K} / \mathrm{Ca},(\mathrm{K}+\mathrm{Mg}) / \mathrm{Ca}$ relationships in apple fruits because these parameters should be better predictors of bitter pit incidence at postharvest compared with only determining the $\mathrm{Ca}$ concentration or other nutrients as individual measurements in fruits at harvest or in young fruits (60 to $80 \mathrm{~d}$ after the bloom stage). Von Bennewitz et al. (2011) have used the $\mathrm{N} / \mathrm{Ca}, \mathrm{K} / \mathrm{Ca}, \mathrm{Mg} / \mathrm{Ca}$, and $(\mathrm{K}+\mathrm{Mg}) / \mathrm{Ca}$ relationships to estimate fruit quality in a fertilization experiment in 'Jonagold' apple orchards in southern Chile. Other authors also suggest the evaluation of other nutritional relationships in fruits to determine bitter pit incidence at postharvest (Opara and Tadesse, 2000); for example, considering $(\mathrm{N}+\mathrm{K}+\mathrm{Mg}) / \mathrm{Ca}$ at harvest or in young fruits (Lepe, 2014) or determining the $\mathrm{Mg}^{2+} / \mathrm{Ca}^{2+}$ ratio in the cortical tissue of apple fruits (de Freitas et al., 2013). In addition, de Freitas et al. (2013) suggested using the $\mathrm{Mg}^{2+} / \mathrm{Ca}^{2+}$ ratio in the cortical tissue of apple fruits to determine bitter pit incidence. 
Considering that different levels of incident light or shade on the tree could affect tissue nutritional concentration and that there is not enough information reported for apples (de Freitas et al., 2013), the impact of using shade cloth in different apple cultivars and under different conditions is required. The objective of our study was to evaluate the effect of shade cloth in a 'Fuji' apple orchard on the fruit nutritional concentration at harvest, leaf mineral concentration for summer standard monitoring, and bitter pit incidence after $120 \mathrm{~d}$ of cold storage.

\section{MATERIALS AND METHODS}

\section{Climatic and soil characteristics}

The experiment was conducted over three consecutive seasons from 2016 to 2019 in a 'Fuji' apple (Malus domestica

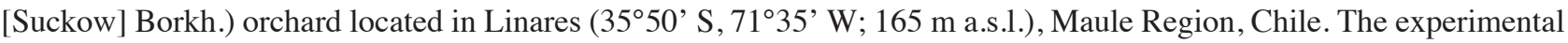
site has an alluvial origin (Vitrandepts) (USDA, 2014) and the climatic conditions observed during each season are shown in Table 1 (Red Agrometeorológica de INIA, 2018). Soil physicochemical properties were analyzed using methods described by Sadzawka et al. (2006) (Table 2). Soil pH was measured in a soil:water solution at a 1:2.5 ratio with a pH electrode (HI 4211, Hanna Instruments, Smithfield, Rhode Island, USA). Soil organic matter was measured by the

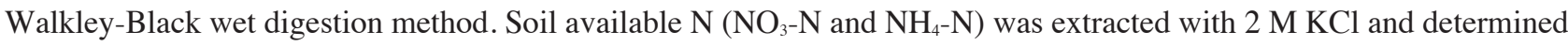
by colorimetry with an autoanalyzer (segmented flux spectrophotometer, Skalar, Breda, The Netherlands). Available P in the soil sample was determined with $0.5 \mathrm{M} \mathrm{NaHCO}_{3}(\mathrm{Olsen} \mathrm{P})$ by the ascorbic acid-molybdate method. Exchangeable $\mathrm{Ca}, \mathrm{Mg}, \mathrm{K}$, and $\mathrm{Na}$ were determined by $1 \mathrm{M} \mathrm{NH}_{4} \mathrm{OAc}$ extraction followed by flame spectroscopy (969 AA; Unicam, Ilminster, $\mathrm{UK}$ ); that is, absorption ( $\mathrm{Ca}$ and $\mathrm{Mg}$ ) and emission ( $\mathrm{K}$ and $\mathrm{Na}$ ). The soil exchangeable $\mathrm{Al}$ concentration was determined by $1 \mathrm{M} \mathrm{KCl}$ extraction with absorption spectroscopy (969, Unicam, Ilminster, UK). Soil Fe, Mn, Zn, and Cu concentrations were determined in diethylenetriaminepentaacetic acid (DTPA) extract by atomic absorption spectrometry (AAS). Boron was determined by colorimetry in a hot water solution (969, Unicam, Ilminster, UK). Soil texture was analyzed by the Bouyoucos hydrometer method.

Soil physicochemical properties evaluated in the experiment were not limitations for apple production according to standards (Palmer and Dryden, 2006) (Table 2); therefore, no chemical amendments were applied prior to starting the experiment.

\section{Treatments and horticultural management practices of the experiment}

The apple orchard used for the study consisted of 'Fuji Raku Raku' apples on a 'Pajam 2' graft planted in 2007 with 4 $\mathrm{m}$ between-row spacing and $1.5 \mathrm{~m}$ in-row spacing. Two treatments were evaluated, a control without shade cloth and a treatment with a black 30\% Raschel shade net cover. The net was installed $4 \mathrm{~m}$ from the ground on 15 November with 2- to 3-cm diameter fruits and removed on 25 March of each growing season (before harvest). Each treatment consisted of five replicates.

Table 1. Climatic characteristics of the experimental site for the three evaluated seasons.

\begin{tabular}{|c|c|c|c|c|c|c|c|c|c|c|c|c|}
\hline & \multicolumn{3}{|c|}{2016} & \multicolumn{3}{|c|}{2017} & \multicolumn{3}{|c|}{2018} & \multicolumn{3}{|c|}{2019} \\
\hline & $\mathrm{Tm}$ & $\mathrm{pp}$ & $\mathrm{Ev}$ & $\mathrm{Tm}$ & $\mathrm{pp}$ & $\mathrm{Ev}$ & $\mathrm{Tm}$ & $\mathrm{pp}$ & $\mathrm{Ev}$ & $\mathrm{Tm}$ & $\mathrm{pp}$ & Ev \\
\hline & ${ }^{\circ} \mathrm{C}$ & \multicolumn{2}{|c|}{$-\mathrm{mm}$} & ${ }^{\circ} \mathrm{C}$ & \multicolumn{2}{|c|}{$-\mathrm{mm}-$} & ${ }^{\circ} \mathrm{C}$ & \multicolumn{2}{|c|}{$-\mathrm{mm}-$} & ${ }^{\circ} \mathrm{C}$ & \multicolumn{2}{|c|}{$-\mathrm{mm}-$} \\
\hline Jan & 19.9 & 5.8 & 138.6 & 20.7 & 3.6 & 182.8 & 19.3 & 0.0 & 134.8 & 19.4 & 0.0 & 134.5 \\
\hline Feb & 18.7 & 0.0 & 129.8 & 20.0 & 0.1 & 123.2 & 19.3 & 0.6 & 116.1 & 19.6 & 1.0 & 100.4 \\
\hline Mar & 15.3 & 0.4 & 26.7 & 16.2 & 4.1 & 94.9 & 15.5 & 26.3 & 99.3 & 15.4 & 1.8 & 94.4 \\
\hline Apr & 12.2 & 118.4 & 40.5 & 12.2 & 11.6 & 53.5 & 11.5 & 40.2 & 46.9 & 11.6 & 2.1 & 45.4 \\
\hline May & 11.4 & 50.2 & 25.0 & 8.5 & 4.4 & 24.5 & 7.4 & 48.0 & 11.0 & 9.2 & 147.5 & 24.4 \\
\hline Jun & 5.3 & 9.1 & 14.9 & 7.1 & 1.6 & 20.7 & 5.4 & 76.4 & 17.1 & & & \\
\hline Jul & 7.5 & 141.1 & 21.9 & 5.7 & 62.1 & 22.6 & 6.1 & 27.2 & 23.2 & & & \\
\hline Aug & 9.1 & 20.4 & 39.0 & 7.6 & 171.6 & 34.7 & 7.4 & 65.2 & 36.8 & & & \\
\hline Sep & 11.5 & 7.6 & 65.7 & 9.8 & 36.2 & 59.3 & 10.7 & 73.6 & 59.1 & & & \\
\hline Oct & 14.0 & 37.3 & 74.0 & 12.1 & 24.1 & 89.9 & 12.4 & 43.9 & 83.2 & & & \\
\hline Nov & 16.7 & 12.0 & 136.6 & 15.7 & 32.6 & 123.9 & 16.3 & 38.1 & 122.5 & & & \\
\hline Dec & 18.0 & 21.6 & 150.1 & 18.6 & 0.6 & 145.9 & 18.6 & 1.2 & 137.5 & & & \\
\hline $\begin{array}{l}\text { Total } \\
\text { accumulated }\end{array}$ & - & 423.9 & 862.8 & - & 352.6 & 975.9 & - & 440.7 & 887.5 & - & 152.4 & 399.1 \\
\hline
\end{tabular}

Tm: Mean temperature; pp: precipitation; Ev: evaporation. 
Table 2. Soil chemical properties at $0.0-0.3 \mathrm{~m}$ depth before the experiment.

\begin{tabular}{lr}
\hline Parameters & Value \\
\hline Clay, \% & 5.20 \\
Silt, \% & 25.80 \\
Sand, \% & 69.00 \\
$\mathrm{pH}_{\text {(soil:wate 1:5) }}$ & 6.85 \\
Organic matter, g kg-1 & 47.20 \\
Available N, mg kg-1 & 4.80 \\
Olsen P, mg kg-1 & 20.00 \\
Exchangeable K, cmol $\mathrm{kg}^{-1}$ & 0.20 \\
Exchangeable Ca, cmolc $\mathrm{kg}^{-1}$ & 9.27 \\
Exchangeable Mg, cmol $\mathrm{kg}^{-1}$ & 1.20 \\
Exchangeable Na, cmolc $\mathrm{kg}^{-1}$ & 0.21 \\
Exchangeable Al, cmol $\mathrm{kg}^{-1}$ & 0.01 \\
Available Fe, mg kg-1 & 27.30 \\
Available Mn, mg kg-1 & 3.49 \\
Available Zn, mg kg-1 & 5.46 \\
Available Cu, mg kg-1 & 6.97 \\
Available B, mg kg-1 & 0.44 \\
Available S, mg kg-1 & 25.60 \\
\hline
\end{tabular}

All apple trees were irrigated with a double line drip irrigation system and drippers with $2 \mathrm{~L} \mathrm{~h}^{-1}$ flow were located every $50 \mathrm{~cm}$ from the trees. The irrigation criterion for trees with or without shade cloth or netting corresponded to $100 \%$ evaporation replacement from October to April of each season (Table 1) and adjusted according to the crop coefficient. Orchard aisles were covered with vegetation consisting of native species, grasses, and legumes. The fertilization scheme is shown in Table 3; phosphoric acid, calcium nitrate, magnesium sulfate, and urea fertilizers were applied by fertigation. Phytosanitary sprays were normal for a commercial apple orchard, emphasizing controls of apple scab (Venturia inaequalis), powdery mildew (Podosphaera leucotricha), nectria canker (Nectria galligena), and moldy core caused by Alternaria spp. and other fungal species (Latorre, 2019). Additionally, 12 foliar $\mathrm{Ca}$ (liquid $\mathrm{Ca}, 16 \% \mathrm{CaO}$ ) sprayings were conducted at 10- to 15-d intervals from flowering onward (October to February). Fruit total yields were 58, 61, and 56 $\mathrm{Mg} \mathrm{ha}^{-1}$ for the 2017, 2018, and 2019 seasons, respectively, there were no differences between the area with and without shade cloth, and fruit load per plant was adjusted by manual thinning to 160 to 170 fruits per tree.

\section{Nutritional analysis of leaves and fruits}

Sample leaves were collected from each treatment and replicate on 30 January in each season. Each leaf sample was collected from the fruitless spurs located at crown height on both sides of the rows (1.5 to $1.8 \mathrm{~m}$ from the ground); each sample included 100 leaves per experimental unit. A total of 25 fruits were collected per experimental unit (Lötze and Theron, 2007) from spurs located at crown height on both sides of the rows for the fruit nutritional analysis at harvest.

Leaf and fruit samples were oven-dried at $70{ }^{\circ} \mathrm{C}$ to constant weight to analyze nutrient content. Evaluated leaf nutrients were $\mathrm{N}, \mathrm{P}, \mathrm{K}, \mathrm{Ca}, \mathrm{Mg}, \mathrm{S}, \mathrm{Fe}, \mathrm{Mn}, \mathrm{Zn}, \mathrm{Cu}, \mathrm{B}$, and $\mathrm{Na}$, whereas evaluated fruit nutrients were $\mathrm{N}, \mathrm{P}, \mathrm{K}, \mathrm{Ca}, \mathrm{Mg}$, and $\mathrm{S}$. The methodologies were those indicated by Sadzawka et al. (2007). Total N was determined by the macro-Kjeldahl procedure (Vadupest, Gerhardt, Germany), total K, Na, Ca, and $\mathrm{Mg}$ by atomic emission (K and $\mathrm{Na}$ ), and atomic absorption (Ca and $\mathrm{Mg}$ ) spectrophotometry after dry ashing at $500{ }^{\circ} \mathrm{C}$ and acid digestion $(2 \mathrm{M} \mathrm{HCl})$ (Spectronic HE $\lambda \mathrm{IOS}$, Thermo Fisher

Table 3. Fertilization management during the experiment.

\begin{tabular}{lrrrrrr}
\hline & $\mathrm{N}$ & $\mathrm{P}_{2} \mathrm{O}_{5}$ & $\mathrm{~K}_{2} \mathrm{O}$ & $\mathrm{CaO}$ & $\mathrm{MgO}$ & $\mathrm{S}$ \\
\cline { 2 - 7 } & \multicolumn{7}{c}{$\mathrm{kg} \mathrm{ha}^{-1}$} & season & -1 \\
Oct & 12 & 5 & 0 & 20 & 5 & 5.8 \\
Nov & 12 & 5 & 0 & 20 & 5 & 5.8 \\
Dec & 0 & 5 & 20 & 0 & 5 & 5.8 \\
Jan & 0 & 5 & 20 & 0 & 5 & 5.8 \\
Feb & 0 & 5 & 20 & 0 & 5 & 5.8 \\
Mar & 0 & 5 & 20 & 0 & 5 & 5.8 \\
Apr & 6 & 5 & 20 & 0 & 0 & 0.0 \\
Total & 30 & 35 & 100 & 40 & 30 & 35.0 \\
\hline
\end{tabular}


Corporation, Waltham, Massachusetts, USA). Phosphorus was measured in the same extracts by colorimetry by the molybdate ascorbic acid method (HEגIOS). Concentrations of $\mathrm{Fe}, \mathrm{Cu}, \mathrm{Zn}$, and $\mathrm{Mn}$ were determined by sample calcination and AAS. The $\mathrm{S}$ concentration was determined by sample calcination and turbidimetry, while the B concentration was detected by sample calcination and colorimetry with azomethine H (HEגIOS).

\section{Bitter pit evaluation}

For the bitter pit evaluations, fruits were collected at harvest maturity from spurs located at crown height on both sides of the rows in boxes of 100 fruits per experimental unit, which were stored in a walk-in freezer maintained below $0{ }^{\circ} \mathrm{C}$ and $85 \%$ humidity for 4 mo (120 d). Fruits were visually evaluated after storage for the presence of bitter pit and classified as either having or not having bitter pit symptoms, regardless of the number of lesions and using a percentage damage classification (Lötze et al., 2006).

\section{Experimental design and statistical analysis}

The field experiment was conducted using a randomized complete block design with two treatments and five replicates (10 experimental units). Each row of trees $60 \mathrm{~m}$ long with a total area of $2400 \mathrm{~m}^{2}$ was defined as an experimental unit. An ANOVA was performed to establish differences among treatments given a split plot design in which the main plot was the season and the split plot was shade cloth treatments. Means comparison was calculated by Tukey's multiple range test at $\mathrm{p} \leq 0.05$ by the SAS general model procedure (SAS Institute, Cary, North Carolina, USA). To separate the effect of treatments with or without shade cloth, contrast analysis was used at 5\% significance. Bitter pit incidence was determined as a percentage and data were transformed by the Bliss square root transformation $(x+0.5)$ to fulfill the ANOVA assumptions.

\section{RESULTS}

\section{Leaf nutrient concentration}

Significance analysis indicated an effect of the season on the N, P, Fe, Mn, Zn, B ( p < 0.01), Ca, and S (p < 0 .05) concentrations (Table 4). The use of shade cloth only affected the $\mathrm{Mn}(\mathrm{p}<0.01), \mathrm{Mg}$, and $\mathrm{Zn}(\mathrm{p}<0.05)$ concentrations (Table 4). However, the season $\times$ shade cloth interaction had no effect on the $\mathrm{N}, \mathrm{P}, \mathrm{Ca}$, and $\mathrm{S}(\mathrm{p}<0.05)$ concentrations (Table 4).

Table 4. Significance analysis of the effect of treatments and interactions on leaf and fruit nutrient concentrations.

\begin{tabular}{|c|c|c|c|}
\hline Leaf nutrient concentration & $\mathrm{Y}$ & $\mathrm{SC}$ & $\mathrm{Y} \times \mathrm{SC}$ interaction \\
\hline $\mathrm{N}$ & $* *$ & ns & $*$ \\
\hline $\mathrm{P}$ & $* *$ & ns & $*$ \\
\hline $\mathrm{K}$ & ns & ns & ns \\
\hline $\mathrm{Ca}$ & $*$ & ns & $*$ \\
\hline $\mathrm{Mg}$ & ns & $*$ & ns \\
\hline $\mathrm{S}$ & $*$ & ns & $*$ \\
\hline $\mathrm{Fe}$ & $* *$ & ns & ns \\
\hline $\mathrm{Mn}$ & $* *$ & $* *$ & ns \\
\hline $\mathrm{Zn}$ & $* *$ & $*$ & $*$ \\
\hline $\mathrm{Cu}$ & ns & ns & ns \\
\hline B & $* *$ & ns & ns \\
\hline $\mathrm{Na}$ & ns & ns & ns \\
\hline Fruit nutrient concentration & $\mathrm{Y}$ & $\mathrm{SC}$ & $\mathrm{Y} \times \mathrm{SC}$ interaction \\
\hline $\mathrm{N}$ & $* *$ & ns & ns \\
\hline $\mathrm{P}$ & $*$ & ns & ns \\
\hline $\mathrm{K}$ & ns & $* *$ & $* *$ \\
\hline $\mathrm{Ca}$ & $*$ & ns & $* *$ \\
\hline $\mathrm{Mg}$ & ns & $* *$ & $*$ \\
\hline S & $* *$ & $* *$ & $* *$ \\
\hline $\mathrm{N} / \mathrm{Ca}$ relationship & $*$ & ns & $* *$ \\
\hline $\mathrm{K} / \mathrm{Ca}$ relationship & ns & ns & $* *$ \\
\hline$(\mathrm{N}+\mathrm{K}+\mathrm{Mg}) / \mathrm{Ca}$ relationship & $*$ & ns & $* *$ \\
\hline Bitter pit & $* *$ & ns & ns \\
\hline
\end{tabular}

Y: Year; SC: shade cloth.

$*$ Significant at $\mathrm{p}<0.05 ; * *$ Significant at $\mathrm{p}<0.01 ;$ ns: nonsignificant. 
The leaf $\mathrm{N}$ concentration fluctuated between $1.84 \%$ and $2.35 \%$, and it was higher in the first two seasons (2016-2017 and 2017-2018) $(\mathrm{p}<0.05)($ Table 5). The effect of the Season $\times$ Shade cloth interaction (Table 4) was erratic. The control had a higher leaf $\mathrm{N}$ concentration in the 2017-2018 season $(\mathrm{p}<0.05)$, whereas there was a higher concentration in the shade cloth treatment in the 2018-2019 season ( $<<0.05)$ (Table 5).

The leaf P concentration varied between $0.18 \%$ and $0.26 \%$, and it was higher in the 2017-2018 season (Table 4). The effect of the Season $\times$ Shade cloth interaction (Table 4) showed a higher leaf P concentration in the shade cloth treatment in the 2018-2019 season $(\mathrm{p}<0.05)$ (Table 5).

The leaf K concentration ranged from $1.12 \%$ to $1.22 \%$ (Table 5). Meanwhile, the Ca concentration varied between $1.36 \%$ and $1.62 \%$, and the highest values were obtained in the 2016-2017 and 2018-2019 seasons (Table 5). The effect of the Season $\times$ Shade cloth interaction (Table 4) showed a higher Ca concentration in the control for the 2017-2018 season $(\mathrm{p}<0.05)$ (Table 5).

The leaf Mg concentration values fluctuated between $0.21 \%$ and $0.24 \%$ (Table 5). The effect of the Season $\times$ Shade cloth interaction (Table 4) produced a higher Mg concentration only in the shade cloth treatment in the 2016-2017 season $(\mathrm{p}<0.05)$ (Table 5).

The leaf $\mathrm{S}$ concentration varied between $0.13 \%$ and $0.15 \%$, and the highest values were found in the 2018-2019 season $(\mathrm{p}<0.05)($ Table 5). The effect of the Season $\times$ Shade cloth interaction (Table 4) displayed a higher S concentration in the shade cloth treatment in the 2018-2019 season $(\mathrm{p}<0.05)$ (Table 5).

The leaf Fe concentration ranged from 59.8 to $113.6 \mathrm{mg} \mathrm{kg}^{-1}$. The highest value was obtained in the 2017-2018 season, whereas the lowest value occurred in the 2018-2019 season ( $<$ < 0.05) (Table 5).

The leaf Mn concentration fluctuated between 132.2 and $296.5 \mathrm{mg} \mathrm{kg}^{-1}$, and the highest value was reached in the 20182019 season $(\mathrm{p}<0.05)$ (Table 5). The effect of the Season $\times$ Shade cloth interaction (Table 4) exhibited a higher Mn concentration in the shade cloth treatment in the 2016-2017 season $(\mathrm{p}<0.05)$ (Table 5).

The leaf $\mathrm{Zn}$ concentration values varied between 24.9 and $75.0 \mathrm{mg} \mathrm{kg}^{-1}$, and the highest value was obtained in the 2018-2019 season $(\mathrm{p}<0.05)$ (Table 5). The effect of the Season $\times$ Shade cloth interaction (Table 4) showed a higher $\mathrm{Zn}$ concentration in the shade cloth treatment in the 2017-2018 season $(\mathrm{p}<0.05)$ (Table 5).

The leaf $\mathrm{Cu}$ concentration ranged from 6.5 to $7.5 \mathrm{mg} \mathrm{kg}^{-1}$ (Table 5). The leaf B concentration values varied between 31.8 and $37.6 \mathrm{mg} \mathrm{kg}^{-1}$, and the highest value occurred in the 2018-2019 season $(\mathrm{p}<0.05)$ (Table 5). Finally, the leaf $\mathrm{Na}$ concentration fluctuated between 109.2 and $190.8 \mathrm{mg} \mathrm{kg}^{-1}$ (Table 5).

Table 5. Effect of Season $\times$ Shade cloth interaction on apple leaf nutrient concentrations.

\begin{tabular}{|c|c|c|c|c|c|c|}
\hline \multirow[b]{2}{*}{ Nutrients } & \multicolumn{2}{|c|}{ 2016-2017 } & \multicolumn{2}{|c|}{ 2017-2018 } & \multicolumn{2}{|c|}{ 2018-2019 } \\
\hline & Control & $\mathrm{SC}$ & Control & $\mathrm{SC}$ & Control & $\mathrm{SC}$ \\
\hline $\mathrm{N}, \%$ & $2.21 \mathrm{aA}$ & $2.35 \mathrm{aA}$ & $2.29 \mathrm{aA}$ & $2.10 \mathrm{bA}$ & $1.84 \mathrm{bB}$ & $2.07 \mathrm{aB}$ \\
\hline $\mathrm{P}, \%$ & $0.20 \mathrm{aB}$ & $0.20 \mathrm{aB}$ & $0.23 \mathrm{aA}$ & $0.26 \mathrm{aA}$ & $0.18 \mathrm{bB}$ & $0.20 \mathrm{aB}$ \\
\hline $\mathrm{K}, \%$ & $1.19 \mathrm{aA}$ & $1.14 \mathrm{aA}$ & $1.15 \mathrm{aA}$ & $1.14 \mathrm{aA}$ & $1.22 \mathrm{aA}$ & $1.12 \mathrm{aA}$ \\
\hline $\mathrm{Ca}, \%$ & $1.48 \mathrm{aA}$ & $1.62 \mathrm{aA}$ & $1.50 \mathrm{aB}$ & $1.36 \mathrm{bB}$ & $1.55 \mathrm{aA}$ & $1.54 \mathrm{aA}$ \\
\hline $\mathrm{Mg}, \%$ & $0.21 \mathrm{bA}$ & $0.23 \mathrm{aA}$ & $0.21 \mathrm{aA}$ & $0.23 \mathrm{aA}$ & $0.22 \mathrm{aA}$ & $0.24 \mathrm{aA}$ \\
\hline $\mathrm{S}, \%$ & $0.13 \mathrm{aB}$ & $0.14 \mathrm{aB}$ & $0.14 \mathrm{aB}$ & $0.13 \mathrm{aB}$ & $0.13 \mathrm{bA}$ & $0.15 \mathrm{aA}$ \\
\hline $\mathrm{Fe}, \mathrm{mg} \mathrm{kg}^{-1}$ & $75.50 \mathrm{aB}$ & $70.30 \mathrm{aB}$ & $113.60 \mathrm{aA}$ & $105.90 \mathrm{aA}$ & $61.70 \mathrm{aC}$ & $59.80 \mathrm{aC}$ \\
\hline $\mathrm{Mn}, \mathrm{mg} \mathrm{kg}^{-1}$ & $132.20 \mathrm{bB}$ & $193.30 \mathrm{aB}$ & $144.80 \mathrm{aB}$ & $174.20 \mathrm{aB}$ & $265.50 \mathrm{aA}$ & $294.50 \mathrm{aA}$ \\
\hline $\mathrm{Zn}, \mathrm{mg} \mathrm{kg}^{-1}$ & $25.00 \mathrm{aB}$ & $32.50 \mathrm{aB}$ & $24.90 \mathrm{bB}$ & $31.10 \mathrm{aB}$ & $72.30 \mathrm{aA}$ & $75.00 \mathrm{aA}$ \\
\hline $\mathrm{Cu}, \mathrm{mg} \mathrm{kg}^{-1}$ & 7.40aA & $6.50 \mathrm{aA}$ & $6.90 \mathrm{aA}$ & $6.80 \mathrm{aA}$ & 7.50aA & $7.50 \mathrm{aA}$ \\
\hline $\mathrm{B}, \mathrm{mg} \mathrm{kg}^{-1}$ & $33.10 \mathrm{aB}$ & $34.80 \mathrm{aB}$ & $31.80 \mathrm{aB}$ & $33.20 \mathrm{aB}$ & $37.60 \mathrm{aA}$ & $36.70 \mathrm{aA}$ \\
\hline $\mathrm{Na}, \mathrm{mg} \mathrm{kg}^{-1}$ & $134.90 \mathrm{aA}$ & $190.80 \mathrm{aA}$ & $109.20 \mathrm{aA}$ & $130.20 \mathrm{aA}$ & $132.80 \mathrm{aA}$ & $120.00 \mathrm{aA}$ \\
\hline
\end{tabular}

Different uppercase letters in the same row indicate differences between seasons according to Tukey's test $(\mathrm{p}<0.05)$. Different lowercase letters in the same row and season indicate differences between treatments according to Tukey's test $(\mathrm{p}<0.05)$.

Control: Without shade cloth; SC: with shade cloth. 


\section{Fruit nutrient concentration and fruit nutrient relationships}

Significance analysis indicated that the season had an effect on $\mathrm{N}$ and $\mathrm{S}(\mathrm{p}<0.01), \mathrm{P}$, and Ca concentrations and the $\mathrm{N} / \mathrm{Ca}$ and $(\mathrm{N}+\mathrm{K}+\mathrm{Mg}) / \mathrm{Ca}$ relationships $(\mathrm{p}<0.05)$ (Table 4). Shade cloth had an effect on the $\mathrm{K}, \mathrm{Mg}$, and $\mathrm{S}$ $(\mathrm{p}<0.01)$ concentrations (Table 4). The Season $\times$ Shade cloth interaction had an effect on the $\mathrm{Mg}(\mathrm{p}<0.05), \mathrm{K}, \mathrm{Ca}$, and $\mathrm{S}$ concentrations and the $\mathrm{N} / \mathrm{Ca}, \mathrm{K} / \mathrm{Ca}$, and $(\mathrm{N}+\mathrm{K}+\mathrm{Mg}) / \mathrm{Ca}$ relationships $(\mathrm{p}<0.01)$ (Table 4).

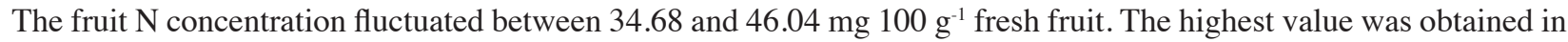
the 2016-2017 season ( $p<0.05$ ), whereas the lowest value was reached in the 2018-2019 season ( $<$ 0.05) (Table 6).

The fruit $\mathrm{P}$ concentration values varied between 9.72 and $11.63 \mathrm{mg} 100 \mathrm{~g}^{-1}$ fresh fruit, and the highest values were obtained in the 2016-2017 and 2017-2018 seasons ( $\mathrm{p}<0.05$ ) (Table 6).

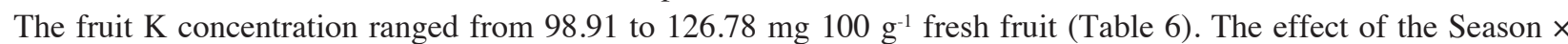
Shade cloth interaction therefore had a higher fruit K concentration in the control treatment for the 2017-2018 and 20182019 seasons $(\mathrm{p}<0.05)$ (Table 6).

The fruit Ca concentration values fluctuated between 4.09 and $7.53 \mathrm{mg} 100 \mathrm{~g} \mathrm{~g}^{-1}$ fresh fruit, and the highest value was reached in the 2017-2018 season ( $\mathrm{p}<0.05)$ (Table 6). The Season $\times$ Shade cloth interaction exhibited an erratic effect of the shade cloth treatment; the highest fruit Ca concentration was obtained in the control in the 2016-2017 season ( $<<0.05)$, whereas the highest value in the 2018-2019 season was attained in the shade cloth treatment $(p<0.05)$ (Table 6).

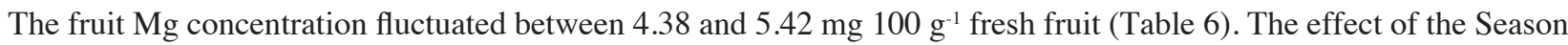
$\times$ Shade cloth interaction therefore had a higher fruit Mg concentration in the control treatment in the 2016-2017 and 2017-2018 seasons $(\mathrm{p}<0.05)$ (Table 6).

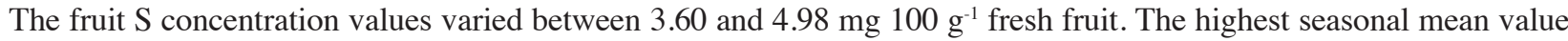
occurred in the 2017-2018 season, followed by the mean value obtained in the 2018-2019 season ( $<$ < 0.05) (Table 6).

Overall, fruit nutritional relationships showed differences between seasons and the effect was erratic (Table 6). The $\mathrm{N} / \mathrm{Ca}$ relationship in fruits fluctuated between 4.76 and 10.59, and the highest value was obtained in the 2016-2017 season $(\mathrm{p}<0.05)$ (Table 6). The Season $\times$ Shade cloth interaction indicated an erratic effect between shade cloth treatments. A higher value was obtained for shade cloth in the 2016-2017 season $(\mathrm{p}<0.05)$, whereas the value was lower for the shade cloth treatment in the 2017-2018 season ( $\mathrm{p}<0.05)$ (Table 6).

The K/Ca relationship in fruits varied between 13.9 and 29.84 (Table 6). The Season $\times$ Shade cloth interaction indicated an erratic effect between shade cloth treatments. The N/Ca relationship had a higher value for shade cloth in the 20162017 season $(\mathrm{p}<0.05)$ and a lower value in the 2017-2018 season $(\mathrm{p}<0.05)$ (Table 6).

The $(\mathrm{N}+\mathrm{K}+\mathrm{Mg}) / \mathrm{Ca}$ relationship in fruits ranged from 19.26 to 41.59 , and the highest mean value when comparing seasons was obtained in the 2016-2017 season $(\mathrm{p}<0.05)$. This value was surpassed only by the mean value in the 20172018 season $(\mathrm{p}<0.05)$ (Table 6). As observed in the calculation of the $\mathrm{N} / \mathrm{Ca}$ and $\mathrm{K} / \mathrm{Ca}$ relationships (Table 6), there was an erratic effect of the Season $\times$ Shade cloth interaction. The highest value of the $(\mathrm{N}+\mathrm{K}+\mathrm{Mg}) / \mathrm{Ca}$ relationship in the 2016-2017 season occurred in the shade cloth treatment $(\mathrm{p}<0.05)$, whereas in the 2017-2018 season the highest value was obtained in the control $(\mathrm{p}<0.05)($ Table 6$)$.

Table 6. Effect of the Season $\times$ Shade cloth interaction on apple fruit nutrient concentrations and nutritional relationship.

\begin{tabular}{|c|c|c|c|c|c|c|}
\hline \multirow[b]{2}{*}{ Nutrients } & \multicolumn{2}{|c|}{$2016-2017$} & \multicolumn{2}{|c|}{$2017-2018$} & \multicolumn{2}{|c|}{ 2018-2019 } \\
\hline & Control & $\mathrm{SC}$ & Control & $\mathrm{SC}$ & Control & $\mathrm{SC}$ \\
\hline $\mathrm{N}, \mathrm{mg} 100 \mathrm{~g}^{-1} \mathrm{FF}$ & $46.04 \mathrm{aA}$ & $43.13 \mathrm{aA}$ & $40.53 \mathrm{aB}$ & $35.65 \mathrm{aB}$ & $36.57 \mathrm{aC}$ & $34.68 \mathrm{aC}$ \\
\hline $\mathrm{P}, \mathrm{mg} 100 \mathrm{~g}^{-1} \mathrm{FF}$ & $11.01 \mathrm{aA}$ & $11.63 \mathrm{aA}$ & $11.40 \mathrm{aA}$ & $10.84 \mathrm{aA}$ & $11.00 \mathrm{aB}$ & $9.72 \mathrm{aB}$ \\
\hline $\mathrm{K}, \mathrm{mg} 100 \mathrm{~g}^{-1} \mathrm{FF}$ & $110.72 \mathrm{aA}$ & $121.51 \mathrm{aA}$ & $122.72 \mathrm{aA}$ & $103.71 \mathrm{bA}$ & $126.78 \mathrm{aA}$ & $98.91 \mathrm{bA}$ \\
\hline $\mathrm{Ca}, \mathrm{mg} 100 \mathrm{~g}^{-1} \mathrm{FF}$ & $6.44 \mathrm{aB}$ & $4.09 \mathrm{bB}$ & $4.70 \mathrm{bA}$ & $7.53 \mathrm{aA}$ & $4.71 \mathrm{aB}$ & $5.03 \mathrm{aB}$ \\
\hline $\mathrm{Mg}, \mathrm{mg} 100 \mathrm{~g}^{-1} \mathrm{FF}$ & $5.42 \mathrm{aA}$ & $4.72 \mathrm{bA}$ & $4.94 \mathrm{aA}$ & $4.43 \mathrm{bA}$ & $4.38 \mathrm{aA}$ & $4.53 \mathrm{aA}$ \\
\hline $\mathrm{S}, \mathrm{mg} 100 \mathrm{~g}^{-1} \mathrm{FF}$ & $4.20 \mathrm{aAB}$ & $4.66 \mathrm{aAB}$ & $4.96 \mathrm{aA}$ & $4.23 \mathrm{bA}$ & $4.45 \mathrm{aB}$ & $3.60 \mathrm{aB}$ \\
\hline $\mathrm{N} / \mathrm{Ca}$ relationship & $7.26 \mathrm{bA}$ & $10.59 \mathrm{aA}$ & $8.75 \mathrm{aB}$ & $4.76 \mathrm{bB}$ & $8.04 \mathrm{aB}$ & $6.98 \mathrm{aB}$ \\
\hline $\mathrm{K} / \mathrm{Ca}$ relationship & $17.55 \mathrm{bA}$ & $29.84 \mathrm{aA}$ & $26.94 \mathrm{aA}$ & $13.90 \mathrm{bA}$ & $27.51 \mathrm{aA}$ & $19.85 \mathrm{aA}$ \\
\hline$(\mathrm{N}+\mathrm{K}+\mathrm{Mg}) / \mathrm{Ca}$ relationship & $25.66 \mathrm{bA}$ & $41.59 \mathrm{aA}$ & $36.75 \mathrm{aB}$ & $19.26 \mathrm{bB}$ & $36.49 \mathrm{aAB}$ & $27.74 \mathrm{aAB}$ \\
\hline
\end{tabular}

Different uppercase letters in the same row indicate differences between seasons according to Tukey's test $(\mathrm{p}<0.05)$. Different lowercase letters in the same row and season indicate differences between treatments according to Tukey's test $(\mathrm{p}<0.05)$.

Control: Without shade cloth; SC: with shade cloth; FF: fresh fruit weight. 


\section{Relationship between bitter pit incidence and fruit nutritional concentrations}

Bitter pit was only affected by the season $(\mathrm{p}<0.01)$, and the shade cloth treatment or Season $\times$ Shade cloth interaction had no effect ( $p>0.05$ ) (Table 4). Values fluctuated between $0.3 \%$ and $6.6 \%$, and the highest values were reached in the 2016-2017 and 2018-2019 seasons ( $<$ <0.05) (Figure 1).

The correlation between bitter pit incidence and fruit $\mathrm{Ca}$ concentration was very low and nonsignificant $(\mathrm{p}>0.05)$ (Figure 2a). Likewise, the correlations between bitter pit incidence and the $\mathrm{N} / \mathrm{Ca}, \mathrm{K} / \mathrm{Ca}$, and $(\mathrm{N}+\mathrm{K}+\mathrm{Mg}) / \mathrm{Ca}$ nutritional relationships in fruits were very low and nonsignificant ( $\mathrm{p}>0.05$ ) (Figures $2 \mathrm{~b}, 2 \mathrm{c}, 2 \mathrm{~d}$ ). The lowest mean values of the $\mathrm{N} /$ $\mathrm{Ca}(6.8), \mathrm{K} / \mathrm{Ca}(20.4)$, and $(\mathrm{N}+\mathrm{K}+\mathrm{Mg}) / \mathrm{Ca}(28.0)$ relationships (Table 6) were obtained in the 2017-2018 season in which bitter pit incidence was the lowest (Figure 1).

Figure 1. Bitter pit incidence in apple fruits with and without shade cloth management over three consecutive seasons (2016-2019).

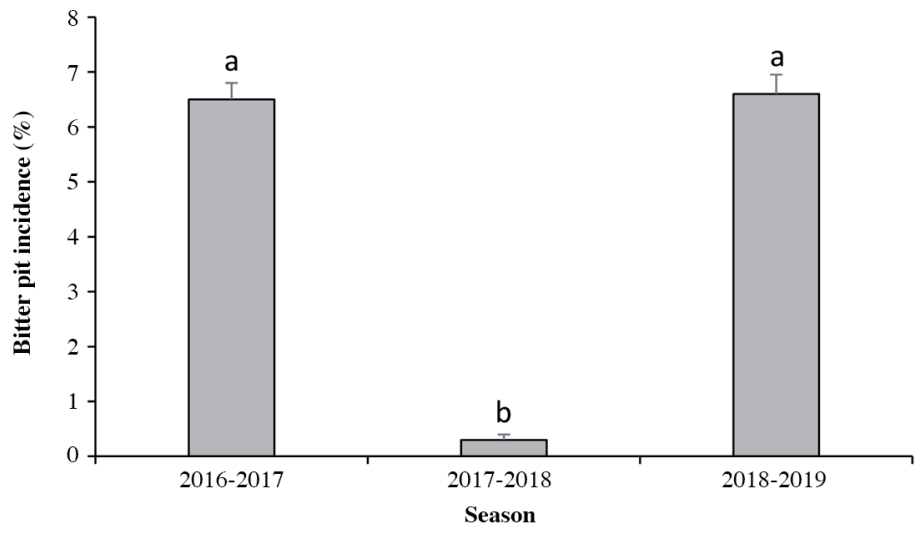

Lines over the bars indicate standard error.

Figure 2. Relationship between bitter pit incidence and fruit Ca concentration in 'Fuji' apples (a), relationship between bitter pit incidence and N/Ca concentration (b), relationship between bitter pit incidence and K/Ca concentration (c), and relationship between bitter pit incidence and $(\mathrm{N}+\mathrm{K}+\mathrm{Mg}) / \mathrm{Ca}$ concentration $(\mathrm{d})$ over three consecutive seasons (2016-2019).
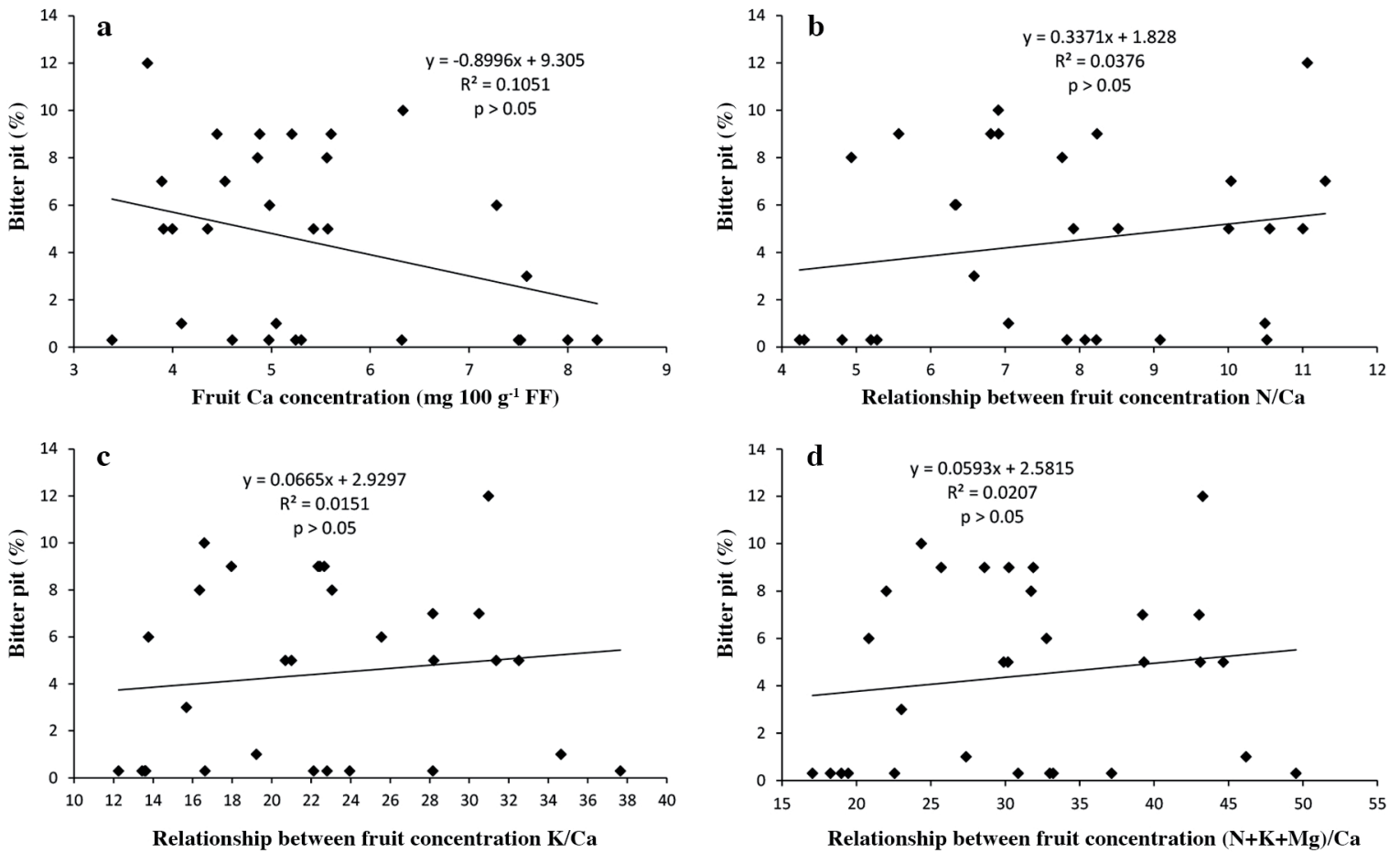


\section{DISCUSSION}

Nutrient concentrations in apple leaves show changes between seasons, which has been reported for this species by Kuresová et al. (2019). In addition, changes in apple leaf nutrients can also be associated with different crop loads, as reported by Brendon et al. (2019). Production was very similar during the three evaluated seasons. The N, S, Cu, and B concentrations in apple leaves were similar to those reported by Brendon et al. (2019) for the same species, whereas the $\mathrm{P}, \mathrm{K}, \mathrm{Ca}, \mathrm{Mg}$, and $\mathrm{Fe}$ concentrations were lower than those indicated by those authors. Results for macronutrients in this study showed that the $\mathrm{N}$ concentration was similar, the $\mathrm{K}$ concentration was lower, and the $\mathrm{P}, \mathrm{Ca}$, and $\mathrm{Mg}$ concentrations were higher compared with findings by von Bennewitz et al. (2011) in the leaves of 'Jonagold' apples in southern Chile. The micronutrient concentrations of $\mathrm{Mn}, \mathrm{Zn}, \mathrm{Cu}$, and $\mathrm{B}$ in leaves were higher than those indicated by Kuresová et al. (2019) for apples. These differences in concentration, based on information published in the literature, can be a response to soil physicochemical properties (Sparrow and Uren, 2014), fungicide or cupric bactericide application management, and soil or leaf nutrient applications. For example, mancozeb (manganese ethylene-bis-dithiocarbamate complex with zinc salt), applied six to eight times during fruit and leaf development to control Venturia inaequalis, can increase both the $\mathrm{Mn}$ and $\mathrm{Zn}$ concentrations. Kuresová et al. (2019) found significant increases in $\mathrm{Zn}$ and B concentrations in apple trees after applying leaf fertilizer with $\mathrm{N}, \mathrm{Ca}, \mathrm{Mg}, \mathrm{Zn}$, and B.

The increased $\mathrm{Mg}$ concentration when using shade cloth can be associated with higher chlorophyll activity and lower negative effect of direct light on this pigment (Demchak, 2009). Increased Mn and Zn concentrations are associated with greater soil moisture conservation (Navarro and Navarro, 2003; Sparrow and Uren, 2014). Shade cloth reduces moisture requirements associated with lower stomatal density (Kim et al., 2011). This higher moisture reduction potential in the soil compared with the treatment with no shade cloth could be associated with the transformation of $\mathrm{Mn}$ and $\mathrm{Zn}$ oxides $\left(\mathrm{MnO}_{\mathrm{n}}\right.$ and $\mathrm{ZnO}_{\mathrm{n}}$ ) into $\mathrm{Mn}^{2+}$ and $\mathrm{Zn}^{2+}$, which increases both their soil availability and plant absorption (Navarro and Navarro, 2003; Sparrow and Uren, 2014). The results of the present study suggest that reference concentrations for $\mathrm{Mg}, \mathrm{Mn}$, and $\mathrm{Zn}$ nutrients in orchards managed with shade cloth could be higher than the standards used for conventional apples (Fallahi et al., 2001) when considering the normal sample collection period to analyze the nutritional status of 'Fuji' apple trees. Sampling was conducted between 16 and 20 wk after bud break, from mid-January to mid-February in the Southern Hemisphere. However, more specific studies are required to determine the appropriate leaf nutritional range in apples.

Overall, fruit nutritional concentrations were similar to those indicated by Palmer and Dryden (2006), $\mathrm{N}$ and $\mathrm{Mg}$ concentrations were similar to those reported by Lötze et al. (2006), and P, K, and Ca concentrations were slightly higher than those mentioned by those authors. The $\mathrm{N}$ and $\mathrm{K}$ rates applied in our experiment ( 30 and $100 \mathrm{~kg} \mathrm{ha}^{-1} \mathrm{yr}^{-1} \mathrm{~N}$ and $\mathrm{K}_{2} \mathrm{O}$, respectively) compared with similar rates used by Nava and Dechen (2009) in a 'Fuji' apple orchard showed that fruit $\mathrm{N}$ and $\mathrm{Ca}$ concentrations in our experiment were slightly higher, although fruit $\mathrm{K}$ concentration was similar to the values reported by those authors. The differences in fruit nutritional concentration between seasons in the present study have also been reported by other authors (Nava and Dechen, 2009; Brendon et al., 2019).

The nutritional relationship in apple fruits has usually been in the range indicated by Lepe (2014) to reduce the risk of bitter pit incidence. Furthermore, the bitter pit level in two seasons was higher than findings reported by Lötze et al. (2006) as tolerance for exportation of apple fruit in South Africa $(<2 \%)$. The mean of the $\mathrm{N} / \mathrm{Ca}, \mathrm{K} / \mathrm{Ca}$, and $(\mathrm{N}+\mathrm{K}+\mathrm{Mg}) / \mathrm{Ca}$ relationships in apple fruits in our experiment was similar to the results by Lötze et al. (2006). In addition, the mean of the N/Ca relationship in apple fruits was lower than the one reported by Lötze et al. (2006) and similar to results reported by Nava and Dechen (2009). Similar N/Ca and K/Ca relationships were observed in our study compared with results reported by von Bennewitz et al. (2011) in 'Jonagold' apples in experiments conducted in southern Chile.

The lack of correlation between the apple fruit nutritional status and bitter pit incidence has also been reported by other authors (Le Grange et al., 1998; Lötze et al., 2006). This nutritional disorder is also associated with climatic variations between seasons (Lötze et al., 2006), hormonal factors (Saure, 1996), and accumulation of toxic substances, such as oxalic and citric acid, that cause the crystallization of calcium salts and cell death on the periphery of the fruit (Steenkamp et al., 1983). Given that the foliar Ca applications were the same in the three seasons and yield was similar in each season, the difference obtained for bitter pit incidence could be associated with the climatic variations between seasons (Lötze et al., 2006). 


\section{CONCLUSIONS}

The results of our study in a 'Fuji' apple orchard showed that shade cloth affected leaf nutritional concentration of some elements interacting with the conditions of each season, increasing leaf concentrations of $\mathrm{Mg}, \mathrm{Mn}$, and $\mathrm{Zn}$ by $0.02 \%, 40$ $\mathrm{mg} \mathrm{kg}^{-1}$, and $5.5 \mathrm{mg} \mathrm{kg}^{-1}$, respectively, as the mean of three seasons. The nutritional concentration in fruits was affected by shade cloth and there was an interaction with the seasons. In general, shade cloth decreased the $\mathrm{K}, \mathrm{Mg}$, and $\mathrm{S}$ concentrations by $12.00,0.35$, and $0.38 \mathrm{mg} 100 \mathrm{~g}^{-1}$ fresh fruit, respectively, as the mean of three seasons. Bitter pit incidence was affected by the season under evaluation, but this abiotic disorder was not affected by the shade cloth treatment.

\section{REFERENCES}

Ayari, O., Dorais, M., and Gosselin, A. 2000. Daily variations of photosynthetic efficiency of greenhouse tomato plants during winter and spring. Journal of American Society of Horticultural Science 125(2):235-241.

Ban, Y., Honda, C., Hatsuyama, Y., Igarashi, M., Bessho, H., and Moriguchi, T. 2007. Isolation and functional analysis of a MYB transcription factor gene that is a key regulator for the development of red coloration in apple skin. Plant Cell Physiology 48:958-970.

Baraldi, R., Rapparini, F., Rotondi, A., and Bertazza, G. 1998. Effects of simulated light environments on growth and leaf morphology of peach plants. Journal Horticultural Science Biotechnology 73:251-258.

Basile, B., Romano, R., Giaccone, M., Barlotti, E., Colonna, V., and Cirillo, C. 2008. Use of photo-selective nets for hail protection of kiwifruit in Southern Italy. Acta Horticulturae 770:185-192.

Bassett, C., Wisniewski, M., Artlip, T., and Norelli, J. 2006. Global analysis of genes regulated by low temperature and photoperiod in peach bark. Journal of American Society of Horticultural Science 131(4):551-563.

Blanke, M. 2007. Farbige Hagelnetze: Ihre Netzstruktur sowie Licht- und UV-Durchlässigkeit bestimmen die Ausfärbung der Apfelfrüchte. Erwerbs-Obstbau 49:127-139.

Brendon, A., Serra, S., and Musacchi, S. 2019. Optimizing crop load for new apple cultivar 'WA38'. Agronomy 9:107.

Castillo-González, A., Avitia-García, E., Valdez-Aguilar, L., Pineda-Pineda, J., and Aguilar-Sánchez, S. 2016. Nutrient dynamics in leaf and fruit of rabbiteye blueberry (Vaccinium ashei Reade). Tecnociencia Chihuahua 10(2):64-71.

Chiabrando, V., and Giacalone, G. 2018. Kiwifruit under plastic covering: impact on fruit quality and on orchard microclimate. Journal of Food, Nutrition and Agriculture 1:1-6. doi:10.21839/jfna.2018.v1i1.113.

Demchak, K. 2009. Small fruit production in high tunnels. HortTechnology 19:44-49.

de Freitas, S.T, Amarante, C.V.T., Dandekar, A.M., and Mitcham, E.J. 2013. Shading affects flesh calcium uptake and concentration, bitter pit incidence and other fruit traits in 'Greensleeves' apple. Scientia Horticulturae 161:266-272. http://dx.doi.org/10.1016/j.scienta.2013.07.019.

Du, W-X., Avena-Bustillos, R., Breksa, A., and McHugh, T. 2014. UV-B light as a factor affecting total soluble phenolic contents of various whole and fresh-cut specialty crops. Postharvest Biology and Technology 93:72-82.

Duan, Y., Xu, Y., Wang, R., and Ma, C. 2019. Investigation and prevention of cork spot disorder in 'Akizuki' pear (Pyrus pyrifolia Nakai). HortScience 54:480-486.

Fallahi, E., Colt, W.M., and Hallahi, B. 2001. Optimum ranges of leaf nitrogen for yield, fruit quality and photosynthesis in 'BC-2 Fuji' apple. Journal of American Pomological Society 55(2):68-75.

Fernández, P., García, F., y Fernández, J. 2014. Estimación de las extracciones de nutrientes en el cultivo de cerezo en la Región de Murcia. Implicaciones del nitrógeno. V Jornadas Fertilización SECH. Actas de Horticultura 66:167-175.

Ho, L.C., Hand, D.J., and Fussell, M. 1999. Improvement of tomato fruit quality by calcium nutrition. Acta Horticulturae 481:463-468.

Kim, S., Yu, D.J., Kim, T.C., and Lee,H.J. 2011. Growth and photosynthetic characteristics of blueberry (Vaccinium corymbosum cv. Bluecrop) under various shade levels. Scientia Horticulturae 129:486-492.

Kuresová, G., Mensík, L., Haberle, J., Svoboda, P., and Raimanová, I. 2019. Influence of foliar micronutrients fertilization on nutritional status of apple trees. Plant, Soil and Environment 65:320-327.

Latorre, B. 2019. Compendio de las enfermedades de las plantas. Ediciones Universidad Católica, Santiago, Chile.

Le Grange, S.A., Theron, K., and Jacobs, G. 1998. Influence of the number of calcium sprays on the distribution of fruit mineral concentration in an apple orchard. Journal of Horticultural Science and Biotechnology 73:569-573.

Lepe, V. 2014. Niveles referenciales de nutrientes y su influencia en la calidad de la fruta. Informe técnico temporadas 20112014. 25 p. Centro de Pomáceas, Facultad de Ciencias Agrarias, Universidad de Talca, Talca, Chile.

Li, K-T., and Syvertsen, J. 2006. Young tree growth and leaf function of citrus seedlings under colored shade netting. HorstScience 41(4):1022.

Lobos, G.A., Retamales, J.B., Hancock, J.F., Flore, J.A., Romero-Bravo, S., and del Pozo, A. 2013. Productivity and fruit quality of Vaccinium corymbosum cv. Elliott under photo-selective shading nets. Scientia Horticulturae 153:143-149. 
Lötze, E., Sadie, A., and Theron, K.I. 2006. Determining the probability of bitter pit in 'Golden delicious' apples through the post-harvest mineral content of individual fruit. Journal of Horticultural Science \& Biotechnology 81:276-280.

Lötze, E., and Theron, K.I. 2007. Evaluating the effectiveness of pre-harvest calcium applications for bitter pit control in 'Golden delicious' apples under South African conditions. Journal of Plant Nutrition 30:471-485.

Martínez-Lüscher J., Lee, C.C., Brillante, L., and Kann, S. 2017. Partial solar radiation exclusion with color shade nets reduces the degradation of organic acids and flavonoids of grape berry (Vitis vinifera L.) Journal of Agricultural and Food Chemistry 65:10693-10702.

Minotta, G., and Pinzauti, S. 1996. Effects of light and soil fertility on growth, leaf chlorophyll content and nutrient use efficiency of beech (Fagus sylvatica L.) seedlings. Forest Ecology and Management 86:61-71.

Mohotti, A., and Lawlor, D. 2002. Diurnal variation of photosynthesis and photoinhibition in tea: effects of irradiance and nitrogen supply during growth in the field. Journal of Experimental Botany 53:313-322.

Nava, G., and Dechen, A.R. 2009. Long-term annual fertilization with nitrogen and potassium affect yield and mineral composition of 'Fuji' Apple. Scientia Agriculturae 66:377-385.

Navarro, S., y Navarro, G. 2003. Química agrícola: El suelo y los elementos químicos esenciales para la vida vegetal. Ediciones Mundi-Prensa, Madrid, España.

Olivares-Soto, H., and Bastías, R.M. 2018. Photosynthetic efficiency of apples under protected shade nets. Chilean Journal of Agricultural Research 70:126-138. doi:10.4067/S0718-58392018000100126.

Opara, L.U., and Tadesse, T. 2000. Fruit growth and mineral element accumulation in Pacific Rose (TM) apple in relation to orchard management factors and calyx-end splitting. Journal of Plant Nutrition 23:1079-1093.

Palmer, J., and Dryden, G. 2006. Fruit mineral removal rates from New Zealand apple (Malus domestica) orchards in the Nelson region. New Zealand Journal of Crop and Horticultural Science 34:27-32.

Red Agrometeorológica de INIA. 2018. [On line] Available at http://agromet.inia.cl/estaciones.php (accessed 26 January 2019).

Retamal-Salgado, J., Vásquez, R., Fischer, S., Hirzel, J., and Zapata, N. 2017. Decrease in artificial radiation with netting reduces stress and improves rabbit-eye blueberry productivity (Vaccinium virgatum Aiton) 'Ochlockonee' productivity. Chilean Journal of Agricultural Research 77:226-233.

Sadzawka, A., Carrasco, M., Demanet, R., Flores, H., Grez, R., Mora, M., et al. 2007. Métodos de análisis de tejidos vegetales. $2^{a}$ ed. Serie Actas INIA N 40. 139 p. Instituto de Investigaciones Agropecuarias (INIA), Santiago, Chile.

Sadzawka, A., Carrasco, M., Grez, R., Mora, M., Flores H., y Neaman, A. 2006. Métodos de análisis recomendados para los suelos de Chile. Revised. Serie Actas INIA N 34. 164 p. Instituto de Investigaciones Agropecuarias (INIA), Santiago, Chile.

Sandri, M.A., Andriolo, J.L., Witter, M., and Dal Ross, T. 2003. Effect of shading on tomato plant grown under greenhouse. Horticultura Brasileira 21:642-645.

Saure, M.C. 1996. Reassessment of the role of calcium in development of bitter pit in apple. Australian Journal of Plant Physiology 23:237-243.

Sharma, S., Singh, R., and Sharma, C. 2005. Periodical changes in foliar macronutrient status of olive. Acta Horticulturae 696:249-254.

Smith, G.S., Clark, C.J., and Buwalda, J.G. 1988. Nutrients dynamics of a kiwifruit ecosystem. Scientia Horticulturae 37:87-109.

Sparrow, L.A., and Uren, N.C. 2014. Manganese oxidation and reduction in soils: effects of temperature, water potential, pH and their interactions. Soil Research 52:483-494.

Steenkamp, J., Terblanche, J.H., and de Villiers, O.T. 1983. The role of organic acids and nutrient elements in relation to bitter pit in golden delicious apples. Acta Horticulturae 138:35-42.

Sun, Y., Feng, H., and Liu, F. 2013. Comparative effect of partial root-zone drying and deficit irrigation on incidence of blossom-end rot in tomato under varied calcium rates. Journal of Experimental Botany 64:2107-2116.

USDA. 2014. Keys to soil taxonomy. $12^{\text {th }}$ ed. 360 p. USDA, Washington D.C., USA.

von Bennewitz, E., Cooper, T., Benavides, C., Losak, T., and Hlusek, J. 2011. Response of "Jonagold" apple trees to $\mathrm{Ca}, \mathrm{K}$ and $\mathrm{Mg}$ fertilization in an andisol in southern Chile. Journal of Soil Science and Plant Nutrition 11(3):71-81. https://dx.doi.org/10.4067/S0718-95162011000300006. 